УДК 347.724:347.9(477)

DOI https://doi.org/10.32849/2663-5313/2019.12.15

\title{
Володимир Цікало,
}

канд. юрид. наук, доиент

доцент кафедри иивільного права та процесу

Львівського національного університету імені Івана Франка

\section{ЗАСАДИ ЗДІЙСНЕННЯ ПРАВ УЧАСНИКІВ ЗА ЗАКОНОМ УКРАЇНИ "ПРО ТОВАРИСТВА 3 ОБМЕЖЕНОЮ ТА ДОДАТКОВОЮ ВІДПОВІДАЛЬНІСТЮ”}

\footnotetext{
Стаття присвячена тендениіям здійснення прав учасників товариств з обмеженою та додатковою відповідальністю.

Однією із засад здійснення корпоративних прав, встановлених Законом Украйни «Про товариства з обмеженою та додатковою відповідальністю», є співвідношення із розміром частки у статутному капіталi.
}

Співвідношення із розміром частки у статутному капіталі господарського товариства може бути двох видів:

1) співвідношення із розміром частки, належної учаснику товариства (наприклад, згідно із ст.ст. 18 та 20 Закону учасник товариства - суб'єкт переважного права купівлі частки - може набути такий обсяг корпоративних прав, що пропонується до продажу, який відповідає (є пропориійним) розміру його частки у статутному капіталі товариства. Цей вид співвідношення слід назвати пропориійністю у здійсненні корпоративних прав);

2) співвідношення із розміром частки, передбаченої Законом (наприклад, відповідно до ст. 413 акону право вимагати проведення аудиторської перевірки діяльності товариства належить не кожному учаснику, а лише тому, частка якого у статутному капіталі товариства становить не менше 10 відсотків. Цей вид співвідношення має назву співрозмірності у здійсненні корпоративних прав).

Більшість дослідників нового Закону одностайно звертає увагу на таку його тендениію, як диспозитивність у здійсненні прав учасників товариств з обмеженою та додатковою відповідальністю. Учасникицихтовариствзгідноіззагальнимправиломздійснюютьсвоїкорпоративніправазурахуванням засади співвідношення із розміром частки у статутному капіталі, тобто пропориійності. Однак із иього загального правила вони можуть на свій розсуд, тобто вільним волевиявленням, встановити винятки. Такі винятки досягаються різними правовими засобами - одностайним рішенням учасників товариства, першою редакцією статуту, змінами до уже чинного статуту.

Можливість внесення кваліфікованою більшістю учасників змін до статуту товариства, якими встановлюеться інший, ніж передбачено законом, порядок здійснення корпоративних прав, має ознаки відступу від пропориійності у їх здійсненні.

Особливості здійснення корпоративних прав учасниками товариств з обмеженою та додатковою відповідальністю дали підстави зробити висновок про те, що законодавець розширив засаду вільного (на власний розсуд) їх здійснення (свободи здійснення). Однак Законом закладена можливість відступу від засади співвідношення (пропориійності) у здійсненні корпоративних прав.

Ключові слова: здійснення, корпоративні права, пропорційність, співвідношення, співрозмірність, тенденції.

Постановка проблеми. Із набранням чинності Законом України «Про товариства 3 обмеженою та додатковою відповідальністю» виникли певні тенденції у здійсненні корпоративних прав їх учасників. Ці тенденції загалом мають позитивний характер, хоча варто звернути увагу і на певні суперечності.

Питанню здійснення корпоративних прав учасників товариств 3 обмеженою та додатковою відповідальністю при- ділили увагу українські вчені, такі як О.В. Бігняк, В.А. Васильєва, О.М. Вінник, Н.С. Глусь, Д.В. Задихайло, Ю.М. Жорнокуй, О.Р. Кібенко, В.М. Коссак, С.С. Кравченко, В.М. Кравчук, Н.С. Кузнєцова, І.В. Лукач, B.В. Луць, Р.А. Майданик, І.Б. Саракун, I.B. Спасибо-Фатєєва. Проте недостатньо дослідженими залишаються новели правового регулювання здійснення прав учасників товариств $з$ обмеженою або додатковою 
відповідальністю, передбачені профільним Законом про ці товариства.

Мета статті. Для вирішення частини окресленої проблеми необхідно встановити тенденції Закону щодо здійснення прав учасників товариств з обмеженою та додатковою відповідальністю, вплив цих тенденцій на правовий статус учасників товариств, можливі варіанти удосконалення положень Закону шодо засад здійснення прав учасників товариств 3 обмеженою та додатковою відповідальністю.

Виклад основного матеріалу. Здійснення корпоративних прав учасників товариств з обмеженою та додатковою відповідальністю підпорядковане певним засадам. Загальні засади здійснення корпоративних прав як різновиду цивільних встановлені у ст. 12 Цивільного кодексу України. Спеціальну засаду здійснення немайнових та майнових прав учасників передбачає Закон України «Про товариства 3 обмеженою та додатковою відповідальністю».

Відповідно до ч. 1 ст. 12 Цивільного кодексу України особа здійснюе свої цивільні права вільно, тобто на власний розсуд. Цю засаду можна назвати засадою свободи у здійсненні корпоративних прав. У науковій літературі її пов'язують із диспозитивністю. Так, на думку Н.С. Кузнєцової, принцип диспозитивності - це вільне користування та розпорядження суб'єктів цивільних правовідносин своїми правами [1, с. 122].

Положення Закону України «Про товариства $з$ обмеженою та додатковою відповідальністю» містять іншу засаду здійснення корпоративних прав. Вона полягає у співвідношенні із розміром частки у статутному капіталі при здійсненні корпоративних прав. Співвідношення із розміром частки y статутному капіталі господарського товариства може бути двох видів:

1) співвідношення із розміром частки, належної учаснику товариства (наприклад, згідно із ст.ст. 18 та 20 Закону учасник товариства - суб'єкт переважного права купівлі частки - може набути такий обсяг корпоративних прав, що пропонується до продажу, який відповідає (є пропорційним) розміру його частки у статутному капіталі товариства. Цей вид співвідношення слід назвати пропориійністю у здійсненні корпоративних прав);

2) співвідношення із розміром частки, передбаченої Законом (наприклад, відповідно до ст. 41 Закону право вимагати проведення аудиторської перевірки діяльності товариства належить не кожному учаснику, а лише тому, частка якого у статутному капі- талі товариства становить не менше 10 відсотків. Цей вид співвідношення має назву співрозмірності у здійсненні корпоративних прав).

У цивілістичній літературі правило про співрозмірність у здійсненні суб'єктивних прав розглядають як досягнення балансу протилежних або суперечливих інтересів, як процес співмірювання протилежних інтересів і забезпечення іх балансу на засадах партнерства (співробітництва) [2, с. 75]. Для здійснення корпоративних прав учасників товариств з обмеженою та додатковою відповідальністю законом про товариства передбачена співрозмірність у здійсненні корпоративних прав учасників з більшою та меншою частками (тобто мажоритарних та міноритарних учасників).

Таким чином, співвідношення із розміром частки у статутному капіталі (співвідношення) як засада здійснення корпоративних прав включає у себе два окремих елементи (два види співвідношення):

- пропориійність у здійсненні корпоративних прав (якщо здійснення корпоративних прав залежить від розміру частки, яка належить учаснику);

- співрозмірність у здійсненні корпоративних прав (якщо здійснення корпоративних прав залежить від розміру частки, передбаченого Законом).

Більшість дослідників Закону «Про товариства з обмеженою та додатковою відповідальністю» звертає увагу на таку його тенденцію, як диспозитивність у регулюванні відносин учасників. Особливо слід звернути увагу на диспозитивність у здійсненні прав учасників товариств з обмеженою та додатковою відповідальністю. Так, Тарас Утіралов відзначає, що закон про ТОВ дає набагато більшу волю учасникам ТОВ [3, с. 1,5$]$ Співавтори статті «Корпоративна реформа: чого очікувати бізнесу?» вважають, що нове законодавче регулювання ТОВ дасть можливість його учасникам здійснювати свої права з більшою диспозитивністю [4, с. 66]. Автор докторської дисертації на тему «Цивільноправовий захист корпоративних прав в Україні» О.В. Бігняк стверджує, що Закон «Про товариства з обмеженою та додатковою відповідальністю» запроваджує багато вимог, які раніше стосувалися виключно акціонерних товариств, але на відміну від Закону України «Про акціонерні товариства» він дозволяє їх застосовувати за бажанням власників бізнесу [5, с. 209].

Підтримуючи оцінку положень Закону України «Про товариства 3 обмеженою та додатковою відповідальністю» про розширення диспозитивності (свободи) у здій- 
сненні корпоративних прав, зазначимо, що треба звернути увагу на його конкретні положення, з урахуванням яких науковці роблять відповідний висновок.

Згідно із ст. 18 Закону України «Про товариства з обмеженою та додатковою відповідальністю» учасникам товариства належить переважне право на участь у збільшенні статутного капіталу товариства за рахунок додаткових вкладів учасників на підставі рішення загальних зборів. При цьому кожний учасник може здійснити своє переважне право, зробивши додатковий вклад у межах суми збільшення статутного капіталу пропориійно до його частки у статутному капіталі. Водночас статутом або одностайним рішенням загальних зборів учасників, в яких взяли участь всі учасники товариства, може встановлюватися можливість учасників вносити додаткові вклади без дотримання пропорцій їніх часток у статутному капіталі (ч. 7 ст. 18 Закону).

Учасник товариства також має переважне право на придбання частки (частини частки) іншого учасника товариства, що продається третій особі (ч. 1 ст. 20 Закону). Якщо кілька учасників товариства скористалися своїм переважним правом, вони набувають частку (частину частки) пропориійно до розміру належних їм часток у статутному капіталі товариства, тобто на пропорційних засадах. Проте відповідно до ч. 6 ст. 20 Закону статутом товариства може встановлюватися інший, зокрема й непропорційний, порядок реалізації переважного права або ж відсутність такого права взагалі.

Одним із основних корпоративних прав учасника товариства з обмеженою або додатковою відповідальністю $є$ право на виплату дивідендів. Відповідно до ч. 1 ст. 26 Закону України «Про товариства 3 обмеженою та додатковою відповідальністю» виплата дивідендів здійснюється особам, які були учасниками товариства на день прийняття рішення про виплату дивідендів, пропориійно до розміру їхніх часток. У ст. 27 Закону передбачені випадки, коли товариство не має права приймати рішення про виплату дивідендів або виплачувати їх. Водночас статут може встановлювати додатково інші умови, за яких загальні збори учасників не можуть приймати рішення про виплату дивідендів чи дивіденди не можуть виплачуватися.

Корпоративним правом учасника товариства 3 обмеженою або додатковою відповідальністю, яке здійснюється на пропориійних засадах, є право на участь у прийнятті рішень вищим органом управління товариством зборами учасників. Згідно із ч. 3 ст. 29 Закону кожен учасник товариства на загальних збо- рах учасників має кількість голосів, пропориійну до розміру його частки у статутному капіталі товариства. Із цього загального правила статутом може бути передбачений виняток, якщо встановлене положення про іншу кількість голосів, належних учасникам товариства (ч. 3 ст. 29 Закону України «Про товариства з обмеженою та додатковою відповідальністю»).

Аналіз змісту Закону України «Про товариства 3 обмеженою та додатковою відповідальністю» дає підстави виділити корпоративні права, пропорційний порядок здійснення яких може бути змінений самими учасниками. До цих корпоративних прав, зокрема, належать такі: переважне право на участь у збільшенні статутного капіталу за рахунок додаткових вкладів (ст. 18 Закону); переважне право на купівлю частки іншого учасника, яку пропонують до продажу третій особі (ст. 20 Закону); право на участь у прийнятті рішень вищим органом управління товариством (загальними зборами) (ст. 29 Закону).

Порядок здійснення корпоративних прав учасників товариств з обмеженою або додатковою відповідальністю як загальне правило передбачений Законом. Учасники товариств ї здійснюють 3 урахуванням засади співвідношення із розміром иастки у статутному капіталі, тобто пропориійності. Однак із цього загального правила учасники товариства можуть на свій розсуд, тобто вільним волевиявленням, встановити винятки. Такі винятки із положень Закону досягаються різними правовими засобами - одностайним рішенням учасників товариства, першою редакцією статуту, змінами до уже чинного статуту.

У разі встановлення порядку здійснення корпоративних прав одностайним рішенням учасників товариства або першою редакцією статуту (підписується всіма учасниками товариства згідно з ч. 2 ст. 11 Закону) необхідна згода усіх учасників (засновників) без винятку. Заперечення хоча б одного учасника (засновника) товариства незалежно від розміру його частки у статутному капіталі виключає можливість зміни порядку здійснення корпоративних прав.

Встановлення порядку здійснення корпоративних прав за допомогою одностайного рішення учасників товариства водночас забезпечує дотримання засади співвідношення із часткою у статутному капіталі в частині співрозмірності $\boldsymbol{y}$ здійсненні корпоративних прав. Співрозмірність при здійсненні корпоративних прав у таких випадках означає наявність балансу між інтересами мажоритарних та міноритар- 
них учасників, тобто учасників із більшою та меншою частками у статутному капіталі товариства. Іншими словами, за умови одностайності у прийнятті рішень зміна законодавчого порядку здійснення корпоративних прав без участі міноритарних учасників не допускається.

Якщо ж встановлений законом порядок здійснення корпоративних прав може бути переглянутий шляхом внесення змін до статуту, то у таких випадках достатньо кваліфікованої більшості голосів учасників. Так, відповідно до ч. 2 ст. 34 Закону України «Про товариства з обмеженою та додатковою відповідальністю» рішення про внесення змін до статуту товариства приймаються трьома чвертями голосів усіх учасників товариства, які мають право голосу з відповідних питань. Це означає, що для зміни встановленого Законом порядку здійснення корпоративних прав внесенням змін до статуту не потрібна згода усіх учасників, а достатньо лише волевиявлення кваліфікованої більшості учасників.

Можливість внесення кваліфікованою більшістю учасників змін до статуту товариства, якими встановлюється інший, ніж передбачено законом, порядок здійснення корпоративних прав, має ознаки відступу від засади пропорційності.

У науковій літературі вчені звертають увагу не лише на позитивні, але й на сумнівні результати впливу Закону України «Про товариства з обмеженою та додатковою відповідальністю». Так, на думку Олександра Гарагонича, у Законі про ТОВ містяться норми, які створюють потенційні загрози для суб'єктів корпоративних правовідносин [6, с. 29].

Однією із загроз Закону України «Про товариства з обмеженою та додатковою відповідальністю» $є$ можливий відступ від засади співвідношення із розміром статутного капіталу, тобто пропорційності, у здійсненні корпоративних прав учасників. На цю обставину в контексті здійснення права на управління товариством з обмеженою відповідальністю звернула увагу Ірина Лукач [7].

Таким чином, Законом України «Про товариства $з$ обмеженою та додатковою відповідальністю» передбачена можливість відступу від засади співвідношення (пропорційності) у здійсненні корпоративних прав за рішенням не усіх учасників товариства, а їх кваліфікованої більшості (3/4 голосів). Це може призвести до випадків, коли визначена більшість учасників товариства з обмеженою або додатковою відповідальністю шляхом внесення змін до статуту встановить інший, тобто непропориійний, порядок здійснення корпоративних прав.
Наведена ситуація, безумовно, вплине на правовий статус учасників із меншою часткою (міноритарних учасників), які можуть втратити юридичну рівність 3 іншими учасниками, зазнати дискримінації.

У сфері корпоративних відносин, окрім засад здійснення иивільних (корпоративних) прав, діють засади, на яких засновані цивільні відносини, встановлені у ст. 1 Цивільного кодексу України. Вони не $€$ тотожними. Засади здійснення корпоративних прав повинні бути узгоджені із засадами цивільних відносин. Дотримання однієї із засад цивільних відносин не може поступатися (шкодити) іншим із них.

Відповідно до ч. 1 ст. 1 Цивільного кодексу України цивільними є особисті немайнові та майнові відносини, засновані на юридичній рівності, вільному волевиявленні, майновій самостійності їх учасників. Українські вчені-цивілісти по-різному характеризують правову природу цих особливостей цивільних відносин. Наприклад, на думку 3.В. Ромовської, юридична рівність, вільне волевиявлення та майнова самостійність - це ознаки цивільних відносин, які існують об'єктивно [8, с. 41]. Н.С. Кузнєцова відносить ці особливості до засад, на яких грунтуються иивільні відносини [1, с. 122] На думку Є.О. Харитонова, вони $є$ характерними ознаками диспозитивного (уповноважувального) елемента иивільно-правового методу правового регулювання [9, с. 122].

Незалежно від того, як визначати правову природу засад цивільних відносин, їх треба розглядати у сукупності, в розумному поєднанні. Жодна із них не повинна мати переваг щодо інших. Свобода волевиявлення не може бути більш пріоритетною, наприклад, ніж юридична рівність. Цивільні відносини об'єктивно не можуть грунтуватися на юридичній нерівності. Отже, юридична рівність $€$ внутрішньою і сутнісною ознакою цивільних відносин, а не ознакою, доданою до них законодавцем [8, с. 41]. Усі засади цивільних відносин, за словами А.С. Довгерта, мають єдиний генний код [10, с. 58].

Такий елемент засади співвідношення із розміром частки у статутному капіталі, як пропорційність у здійсненні корпоративних прав, є засобом забезпечення дотримання юридичної рівності між учасниками товариства. Завдяки пропорційності в учасників із меншим розміром частки (міноритарних учасників) зберігається юридична рівність із іншими (мажоритарними) учасниками товариства. Відступ від пропорційності у здійсненні корпоративних прав означає відступ від юридичної рівності всіх учасників. 
3 метою уникнення відступу від такої засади цивільних відносин, а також для удосконалення положень Закону України «Про товариства з обмеженою та додатковою відповідальністю» в частині здійснення корпоративних прав пропонуємо виключити із Закону випадки можливого скасування правила про пропориійність у їх здійсненні шляхом внесення змін до статуту більшістю голосів учасників. Такі зміни, якщо й уважати їх допустимими, мають бути внесені лише одностайністю голосів усіх учасників товариства, що дозволить також зберегти співрозмірність у здійсненні корпоративних прав.

\section{Висновки}

Більшість дослідників нового Закону звертає увагу на таку його тенденцію, як диспозитивність у здійсненні прав учасників товариств з обмеженою та додатковою відповідальністю.

Згідно із загальним правилом, встановленим законом, учасники товариства здійснюють свої корпоративні права з урахуванням вимоги пропорційності. Однак із цього загального правила самі учасники можуть на свій розсуд, тобто вільним волевиявленням, встановити винятки. Такі винятки досягаються різними правовими засобами - одностайним рішенням учасників товариства, першою редакцією статуту, змінами до уже чинного статуту.

Законом України «Про товариства 3 обмеженою та додатковою відповідальністю» передбачена можливість відступу від засади співвідношення (пропорційності) у здійсненні корпоративних прав за рішенням не усіх учасників товариства, а їх кваліфікованої більшості (3/4 голосів).

\section{Список використаних джерел:}

1. Кузнєцова Н.С. Основні завдання Книги першої проєкту Цивільного кодексу України. Кодифікація приватного (цивільного) права України / за ред. проф. А. Довгерта. Київ : Український центр правничих студій, 2000. 336 с.

2. Майданик Р.А. Розвиток приватного права України : монографія. Київ : Алерта, 2016. 226 с

3. Утіралов Т. Новий закон про ТОВ: для кого і для чого? Юридична газета. № 16 (618). 17.04.2018.

4. Дейненко Є., Кильчинська Ю. Корпоративна реформа: чого очікувати бізнесу? Юридична газета. № 16 (618). 17.04.2018.

5. Бігняк О.В. Цивільно-правовий захист корпоративних прав в Україні : дис. ... докт. юрид. наук : 12.00.03 «Цивільне право і цивільний процес; сімейне право; міжнародне приватне право»; Національний університет «Одеська юридична академія», Одеса, 2018. URL: http://dspace. onua.edu.ua/handle/11300/10739?show=full.

6. Гарагонич О. 10 пасток Закону про ТОВ. URL: http://blog.liga.net/user/ogaragonych/article $/ 30270$

7. Лукач I. Принцип пропорційності частки в статутному капіталі товариства 3 обмеженою відповідальністю праву на управління. Право Украйни. № 8. 2019. С. 145-155. URL: http:// pravoua.com.ua.

8. Ромовська 3.В. Проблеми загальної теоpiї права у проєкті Цивільного кодексу України. Кодифікачія приватного (цивільного) права України / за ред. проф. А. Довгерта. Київ : Український центр правничих студій, 2000. 336 с.

9. Харитонов Є.О. Нариси теорії цивілістики (поняття та концепти) : монографія. Одеса : Фенікс, 2008. 464 с.

10. Довгерт А.С. Проблеми кодифікації приватного (цивільного) права в Україні наприкінці ХХ століття. Кодифікація приватного (иивільного) права України / за ред. проф. А. Довгерта. Київ : Український центр правничих студій, 2000. 336 с.

The paper deals with the tendencies of exercise of the rights of participants of limited liability and additional liability partnerships.

One of the fundamentals of corporate rights exercise set by the Law of Ukraine "On Limited Liability and Additional Liability Partnerships" is the correlation with a share size in the statute capital. In turn, the correlation with a size of a share in the statute capital of an economic partnership can be of two types:

1) correlation with a size of a share that belongs to a participant of a partnership (for example, according to Art. 18 and 20 of the law, a participant of a partnership - a subject of the pre-emptive right to purchase the share, may acquire the amount of corporate rights offered for sale which corresponds to (is proportional to) the size of his share in the statute capital of the partnership: this kind of correlation should be called "proportionality" in the exercise of corporate rights);

2) correlation with a size of a share provided for by law (for example, according to Art. 41 of the law, not every participant has the right to request an audit of the partnership's activities, but only the one whose share size in the statute capital of the partnership is not less than 10 percent: this type of correlation is called "commensurability" in the exercise of corporate rights).

Most researchers of the new law unanimously pay attention to such its tendency as dispositiveness in exercise of the rights of participants of limited liability and additional liability partnerships. Participants of these partnerships, as a general rule, exercise their corporate rights based on the fundamental of correlation with a size of a share in the statute capital, namely, proportionality. Moreover, such exceptions can be 
achieved by various legal means: unanimous decision of the participants of the partnership; the first version of the statute; amendments to the current statute.

Ability of amending the statute of the partnership by the qualified majority of participants on the legislative order for the exercise of corporate rights is endowed with features of deviation from proportionality in their exercise.

Peculiarities of exercise of corporate rights of participants of limited liability and additional liability partnerships lead to the conclusion that the legislator has broadened the fundamental of free exercise of these rights at the discretion of their subject (freedom of exercise). Moreover, the law provides for the possibility of deviation from the fundamental of correlation (proportionality) in the exercise of corporate rights.

Key words: exercise, corporate rights, proportionality, correlation commensurability, tendencies. 